\title{
A DIVERZITÁSBIOLÓGIAI BIZOTTSÁG ÁLLÁSFOGLALÁSA A NÖVÉNYTÁRI FELTERJESZTÉS ÜGYÉBEN
}

Az MTA Diverzitásbiológiai Tudományos Bizottsága 2018. február 9-én egyhangúlag, támogatólag elfogadta Podani János akadémikus elöterjesztését a Magyar Természettudományi Múzeum Növénytárának helyzetéről, a helyzet megoldására tett javaslatokkal együtt.

A Bizottság állásfoglalását az alábbiakban rögzíti, és kéri az Osztály támogatását.

- Az Emberi Erőforrások Minisztériuma haladéktalanul függessze fel a Növénytár területének további csökkentését elrendelö intézkedését. Értékelésünk szerint ez teljesen ellehetetleníti az adott intézmény hazai és regionális tudományos és közmüvelődési feladatainak ellátását, illetve az ott őrzött és gondozott pótolhatatlan nemzeti kincs értékü herbárium anyagok és jeles elödeink hagyatékának további fennmaradását. A botanika szakterületén ez nemcsak az ország és a Kárpát-medence, hanem a Balkántól a Baltikumig terjedő egész Kelet-Közép-Európai Régió legjelentősebb tudományos gyüjteménye, így kiemelt figyelmet érdemel az MTA és a Kormány szintjén egyaránt.

- Korábbi, az Osztály által is támogatott állásfoglalásunkra (2016. 02. 09.) is utalva, halaszthatatlannak tartjuk az egész Magyar Természettudományi Múzeum helyzetének minden oldalú (épület, infrastruktúra, kutatói, megőrző és közművelődési személyi állomány, főhatóság) végleges, a jelenlegi európai gyakorlat élvonala szintjének megfelelö megoldását. Széles körü személyes tapasztalatok és releváns közlemények egyaránt azt bizonyítják, hogy a jelenlegi európai és észak-amerikai nagy természettudományos gyüjtemények, biodiverzitás-kutató- és -tudásközpontok létrehozásának és fejlesztésének szükségességét a bioszféra jelen és várható helyzete, fenyegetettsége messzemenően indokolja. Mindez az MTA és a kormány együttes, sürgös és összehangolt intézkedéseit igényli. 